Al Maal : Journal of Islamic Economics and Banking

http://jurnal.umt.ac.id/index.php/jieb

E-ISSN : $2580-3816$

Vol : 2 No. 1 Bulan Juli Tahun 2020

Hlm : $13-24$

DOI : $\quad$ : 10.31000/almaal.v2i1.2642

\title{
Analisis Efektivitas Penyaluran Zakat Pada Rumah Zakat
}

\author{
Efri Syamsul Bahri ${ }^{1 *}$, Zainal Arif ${ }^{2}$ \\ ${ }^{1}$ Prodi Akuntansi Syariah, Sekolah Tinggi Ekonomi Islam SEBI, Depok, Indonesia \\ ${ }^{2}$ Prodi Perbankan Syariah, Universitas Muhammadiyah Tangerang, Indonesia \\ *efri.sb@sebi.ac.id
}

\begin{abstract}
The purpose of this study was to measure the effectiveness of the distribution of zakat and donations/charity at the Rumah Zakat. This research uses a literature study and quantitative method with the Allocation to Collection Ratio (ACR) ratio measurement model based on Zakat Core Principle (ZCP). The object used in this study is the financial statements of the Rumah Zakat for the period of 2010 to 2019. The results of the study show that distribution includes 8 asnaf, namely: the poor, poor, Amil, converts, Riqob, Ghorimin, Ibnu Sabil and Fii Sabilillah, in four groups empowerment namely: Healthy Smiles, Champion Smiles, Independent Smiles, and Sustainable Smiles with an Integrated Community Development (ICD) approach that is aligned with the Millennium Development Goals (MDGs). Based on ZCP the effectiveness of distribution for 5 years of operation is $87 \%$ or included in the Effective category, where the Alocation to Collection Ratio (ACR) reaches 70-89\%. That is, zakat and donation / alms are channeled to mustahik effectively. Suggestion from this research is that Rumah Zakat can increase the effectiveness of zakat distribution with an effectiveness level above $90 \%$ so that it is included in the Highly Effective category if $A C R \geq 90$ percent).
\end{abstract}

Keywords: Effectiveness; Disbursement; Rumah Zakat; Zakat Core Principle.

\section{ABSTRAK}

Tujuan penelitian adalah untuk mengukur efektivtas penyaluran zakat dan infak/sedekah pada Rumah Zakat. Penelitian ini menggunakan metode studi pustaka dan kuantitaif dengan model pengukuran rasio Allocation to Collection Ratio (ACR) berdasarkan Zakat Core Prinsiple (ZCP). Objek yang digunakan dalam penelitian ini adalah laporan keuangan Rumah Zakat selama rentang periode 2010 sampai dengan 2019. Hasil penelitian menunjukkan penyaluran mencakup 8 asnaf yaitu: Fakir, Miskin, Amil, Muallaf, Riqob, Ghorimin, Ibnu sabil dan Fii sabilillah, pada empat rumpun program pemberdayaan yaitu: Senyum Sehat, Senyum Juara, Senyum Mandiri, dan Senyum Lestari dengan pendekatan Integrated Community Development (ICD) yang selaras dengan Tujuan Pembangunan Millenium atau Millenium Development Goals (MDGs). Berdasarkan ZCP tingkat efektivitas penyaluran selama 5 tahun beroperasi sebesar $87 \%$ atau termasuk dalam kategori Effective, dimana Alocation to Collection Ratio (ACR) mencapai 7089\% persen. Artinya, zakat dan infak/sedekah disalurkan kepada mustahik secara efektif. Saran dari penelitian ini adalah agar Rumah Zakat dapat meningkatkan efektivitas penyaluran zakat dengan tingkat efektivitas di atas 90\% sehingga masuk dalam kategori Highly Effective jika ACR $\geq 90$ persen).

Kata kunci : Efektivitas; Penyaluran; Rumah Zakat; Zakat Core Prinsiple. 


\section{Pendahuluan}

Undang-Undang Nomor 23 Tahun 2011 Tentang Pengelolaan Zakat menyebutkan bahwa untuk membantu Badan Amil Zakat Nasional (BAZNAS) dalam pelaksanaan pengumpulan, pendistribusian, dan pendayagunaan zakat, masyarakat dapat membentuk Lembaga Amil Zakat (LAZ). LAZ (Mubarok dan Fanani 2014) adalah OPZ yang sepenuhnya dibentuk oleh masyarakat dan dikukuhkan oleh pemerintah (Indrawati 2016) dan berperan dalam pelaksanaan pengumpulan, dan pendistribusian zakat di Indonesia (Pratama dan Cahyono 2019).

Berdasarkan data Statistik Zakat Nasional 2018, jumlah LAZ yang ada di Indonesia (BAZNAS 2019) saat ini terdiri dari 68 LAZ (23 LAZ nasional, 12 LAZ provinsi, dan 33 LAZ kabupaten/kota). Dari sisi jumlah menggambarkan bahwa jumlah LAZ di Indonesia semakin menjamur sebagaimana diilustrasikan pada Gambar 1. Hal ini perlu disambut positif mengingat kondisi geografis Indonesia yang begitu luas dan secara demografis jumlah ummat Islam terbesar di dunia.

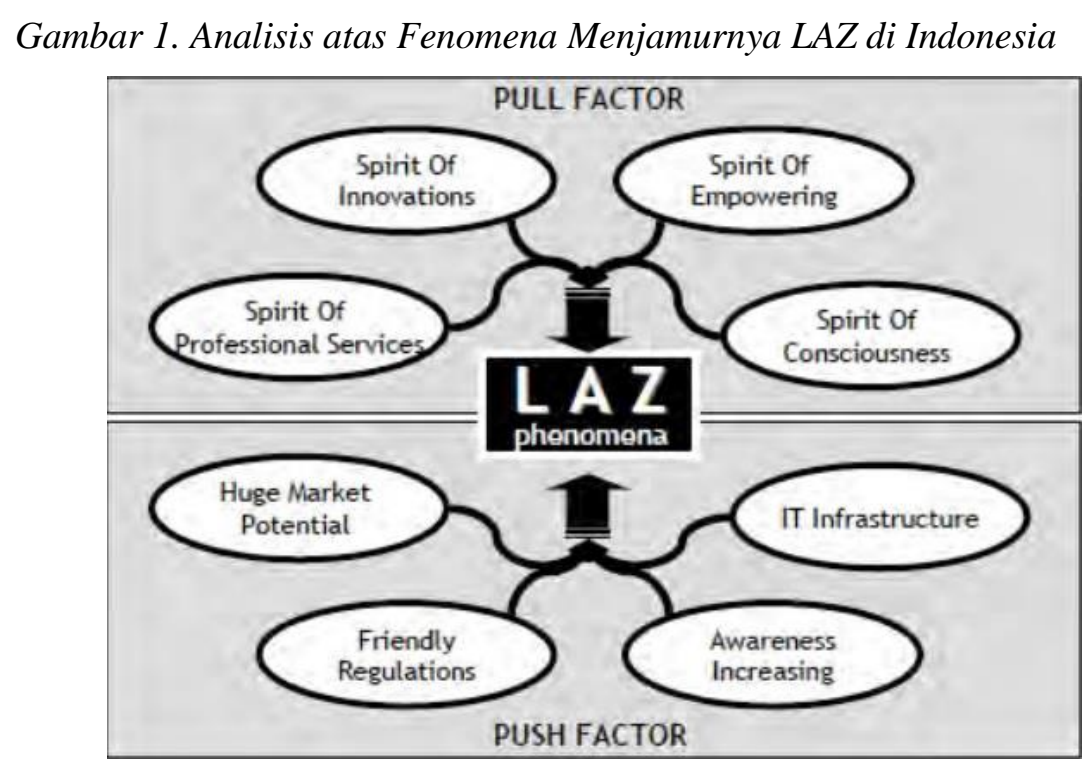

Sumber: (Mubarok dan Fanani 2014)

Selain itu, hal ini menjadi jawaban atas masih rendahnya jumlah pengumpulan zakat secara nasional bila dibandingkan dengan junlah potensinya. Hasil penelitian (Canggih, Fikriyah, dan Yasin 2017) menyebutkan bahwa ketimpangan antara potensi dan realisasi zakat berkisar pada $0.06 \%$ pada tahun $2011,0.068 \%$ pada tahun 2012 , $0.075 \%$ pada tahun 2013, $0.089 \%$ pada tahun 2014, dan $0.09 \%$ pada tahun 2015. Salah satu penyebabnya menurut (Mubarok dan Fanani 2014) adalah masih rendahnya efisiensi dan efektivitas pendayagunaan dana zakat. Namun bila dilihat kontribusinya dalam pengelolaan zakat di Indonesia, kontribusi LAZ terbukti begitu besar. Hal ini dapat dilihat dari data Statistik Zakat Nasional 2018 pada Tabel 1.

Dari jumlah Pengumpulan Dana secara nasional pada tahun 2018 sebanyak Rp8,117,597,683,267,- sebesar 44,77\% berasal dari pengumpulan Dana yang dilakukan oleh LAZ baik LAZ Nasional, LAZ Provinsi dan LAZ Kabupaten/Kota.atau sejumlah Rp3,634,332,619,382. Begitu juga dengan penyaluran Dana. Dari jumlah penyaluran dana secara nasional pada tahun 2018 sebanyak Rp6,800,139,133,196,- sebesar 45,59\% 
berasal dari Penyaluran Dana yang dilakukan oleh LAZ baik LAZ Nasional, LAZ Provinsi dan LAZ Kabupaten/Kota atau sejumlah Rp3,100,034,381,065,-.

Table 1. Pengumpulan dan Penyaluran Dana Berdasarkan Tingkat OPZ

\begin{tabular}{llllll}
\hline Tingkatan OPZ & \multicolumn{1}{c}{$\boldsymbol{P}$ Pengumpulan } & \multicolumn{2}{c}{ Penyaluran } & \multicolumn{1}{c}{$\begin{array}{c}\text { Daya } \\
\text { Serap }\end{array}$} \\
& \multicolumn{1}{c}{$\boldsymbol{p}$} & $\boldsymbol{\%}$ & $\boldsymbol{R} \boldsymbol{p}$ & $\boldsymbol{\%}$ & \\
\hline BAZNAS & $206,374,175,575$ & 2.54 & $235,664,651,030$ & 3.47 & $83.77 \%$ \\
BAZNAS Provinsi & $552,209,167,922$ & 6.80 & $462,230,919,380$ & 6.80 & \\
BAZNAS & $3,171,701,720,388$ & 39.07 & $2,490,478,790,649$ & 36.62 & \\
Kabupaten/Kota & & & & & \\
LAZ & $3,634,332,619,382$ & 44.77 & $3,100,034,381,065$ & 45.59 & \\
OPZ Dalam & $552,980,000,000$ & 6.81 & $511,730,391,073$ & 7.53 & Efektif \\
$\begin{array}{l}\text { Pembinaan } \\
\text { Kelembagaan }\end{array}$ & & & & & \\
Total & $8,117,597,683,267$ & 100.00 & $6,800,139,133,196$ & 100.00 & \\
\hline
\end{tabular}

Sumber: (BAZNAS 2019)

Hal ini menunjukkan kontribusi LAZ baik dalam Pengumpulan maupun Penyaluran sangat siknifikan, kontribusinya menurut (Bayinah 2019) bagi pembangunan bangsa dan mendukung program pemerintah. Bahkan kontribusinya kontribusi (Nasrulloh 2019) sangat holistis pada keberlangsungan kesejahteraan mustahik. Di masa lalu, pada beberapa masa kepemimpinan khalifah-khalifah daulah Umayyah dan Abbasiyah (Marasabessy 2017) telah terbukti bahwa zakat berkontribusi dalam memakmurkan dan memajukan umat dan peradaban Islam. Bahkan zakat yang terkumpul (Efri S. Bahri 2013) menjadi salah satu sumber tetap perbendaharaan Islam (Baitulmaal) dan digunakan untuk kepentingan ummat (Efri Syamsul Bahri 2015).

Menurut Yusuf Qardhawi (2005); (Wulansari dan Setiawan 2014), peranan zakat tidak hanya terbatas pada pengentasan kemiskinan namun juga berguna untuk mengatasi permasalahan-permasalahan kemasyarakatan lainnya, menjadi salah satu instrumen paling efektif membantu permasalahan kemiskinan (Efri Syamsul Bahri dan Khumaini 2020). Zakat juga memainkan peran penting dalam meminimalkan kesenjangan ekonomi di kalangan umat Islam (Yaacob et al. 2013) serta menjadi instrumen kesejahteraan dalam rangka mengatasi masalah ekonomi (Johari, Ali, dan Aziz 2018).

Salah satu LAZ yang mempunya kinerja terbaik adalah Rumah Zakat. Hasil kajian (Pratama dan Cahyono 2019) melalui Malmquist Productivity Index yang dilihat dari skor TFP Change menunjukkan Rumah Zakat Indonesia memiliki peningkatan produktivitas pada tahun 2010 hingga 2017. Hal ini ditunjukan dari besaran skor lebih dari 1.000 pada tahun 2014 dan 2015.Begitu juga dalam hal efisiensi, kinerja Rumah Zakat di Indonesia mampu menjalankan fungsinya dengan tingkat efisiensi $100 \%$.

Hasil kajian (Andriyanto 2011) juga menunjukkan bahwa salah satu lembaga yang terbukti telah mampu mengelola zakat secara terpercaya, transparan, dan profesional adalah Rumah Zakat Indonesia (RZI). Model program yang dikembangkan oleh Rumah Zakat adalah program Integrated Community Development (ICD) dimana program dilakukan secara terintegrasi sehingga dapat memberdayakan masyarakat miskin. Untuk memastikan keberhasilan program tersebut, maka Rumah Zakat menetapkan dan menggunakan Standar Operational Procedure (SOP) sehingga program dapat dikontrol dan pemberdayaan dapat dilakukan dengan transparan dan akuntabel. Prosedur menjadi salah satu bentuk pengendalian intern (COSO, 1992:16-18); (Fadilah 2011) dan bentuk 
penerapan prinsip akuntabilitas sehingga kegiatan penyaluran dana menjadi (Yulinartati, Roziq, dan Ekaningsih 2013). Dalam konteks horizontal, akuntabilitas terkait dengan tanggung jawab kepada manusia, sedangkan secara vertikal merupakan bentuk dalam menjalankan amanah kepada Allah SWT (Athifah, Bayinah, dan Bahri 2018).

Keberhasilan Rumah Zakat ini tentu sejalan dengan Undang-Undang No.23 Tahun 2011 Tentang Pengelolaan Zakat yang menyebutkan bahwa tujuan pengelolaan zakat adalah untuk meningkatkan efektivitas dan efisiensi pelayanan dalam pengelolaan zakat, dan meningkatkan manfaat zakat untuk mewujudkan kesejahteraan masyarakat dan penanggulangan kemiskinan. Oleh karena itu, menjadi penting untuk dilakukan pengukuran efektivitas (Bastiar dan Bahri 2019) penyaluran zakat ini pada Rumah Zakat ini. Sehingga diharapkan dapat menjawab persoalan yang dikemukakan (Mubarok and Fanani 2014) terkait dengan masih rendahnya efektivitas pendayagunaan dana zakat.

Dari uraian latar belakang diatas peneliti tertarik untuk meneliti tentang efektivitas penyaluran zakat termasuk di dalamnya di dalamnya infak/sedekah serta dana kemanusiaan yang dikelola Rumah Zakat. Oleh karena itu judul penelitian ini adalah "Analisis Efektivitas Penyaluran Zakat pada Rumah Zakat".

\section{KAJIAN LITERATUR Definisi Zakat}

Secara harfiah zakat (Yaacob et al. 2013) berarti tumbuh, meningkat, dan memurnikan. Zakat menurut (Aibak, 2015); (Efri Syamsul Bahri, Ariwibowo, dan Robbani 2020) merupakan bagian dari rukun Islam, kedudukannya sama pentingnya dengan shalat (Hudayati dan Tohirin 2010). Zakat adalah satu rukun yang bercorak sosial ekonomi dari lima rukun Islam (Satori Ismail et al. 2018). Ditinjau dari segi bahasa menurut Ibnu Manzur (h.358); (Syahriza, Harahap, dan Fuad 2019) kata zakat merupakan kata dasar (mașdar) dari "zakā (اكز)" yang berarti suci, berkah, tumbuh, kebaikan dan terpuji. Zakat menurut Yusuf Qardhawi (1993); (Satori Ismail et al. 2018) merupakan ibadah maaliyah ijtimaa'iyyah (ibadah harta yang memiliki dimensi sosial), memiliki posisi yang strategis dan menentukan. Zakat (Riyaldi 2017) juga merupakan hak tertentu dalam harta orang-orang yang kaya yang wajib dibagikan kepada golongan yang berhak menerima (asnaf) zakat.

Zakat merupakan kewajiban yang diperintahkan langsung oleh Allah SWT dalam Al-Quran (Efri Syamsul Bahri dan Oktaviani 2019). Hal ini sebagaimana firman Allah dalam QS: at-Taubah ayat 103, "Ambillah zakat dari sebagian harta mereka, dengan zakat itu kamu membersihkan dan mensucikan mereka". Kewajiban zakat (Wulansari dan Setiawan 2014) juga dijelaskan di dalam Undang-Undang nomor 23 Tahun 2011 pasal 1 dan pasal 2 dijelaskan bahwa zakat adalah harta yang wajib dikeluarkan oleh seorang muslim atau badan usaha untuk diberikan kepada yang berhak menerimanya sesuai dengan syariat islam.

Menurut (Said et al, 2011); (Hazlina Abdul Halim, Jamaliah Said 2012), zakat merupakan sumber keuangan yang penting untuk memulai ekonomi masyarakat Muslim dan memberikan dampak pada pembangunan sosial-ekonomi bangsa, instrumen keuangan sosial (Wulan, Khairunnisa, dan Bahri 2018), salah satu ciri dari sistem ekonomi Islam (Khumaini dan Apriyanto 2018). Bahkan zakat dalam sejarah perkembangan Islam menjadi sumber penerimaan negara (Marasabessy 2017). Bagi 
perusahaan yang menunaikan zakat perusahaannya, menurut (Triyuwono, 1997:25); (Triyuwono 2001) zakat menjadi ukuran kinerja materi dan spiritual (etika) sehingga tidak hanya menggunakan ukuran net profit.

\section{Penyaluran Zakat}

Di dalam Kamus Besar Bahasa Indonesia (KBBI); (Efri Syamsul Bahri dan Khumaini 2020) dijelaskan bahwa yang dimaksud dengan penyaluran adalah proses, cara, perbuatan menyalurkan. (KBBI). Dengan demikian, di dalam konteks zakat, maka penyaluran yang dimaksud disini adalah proses, cara, perbuatan dalam menyalurkan zakat kepada yang berhak, yang disebut dengan istilah mustahiq (Indrawati 2016) yaitu: orang yang menerima zakat.

Hal ini sebagaimana termaktub dalam Al-Qur'an pada surat At-Taubah ayat 60 "Sesungguhnya zakat-zakat itu, hanyalah untuk orang-orang fakir, orang-orang miskin, amil zakat, para mualaf yang dibujuk hatinya, untuk (memerdekakan) budak, orang-orang yang berutang, untuk jalan Allah dan untuk mereka yang sedang dalam perjalanan, sebagai suatu ketetapan yang diwajibkan Allah, dan Allah Maha Mengetahui lagi Maha Bijaksana" (QS At-Taubah: 60).

Sedangkan, dalam tinjauan regulasi, menurut Undang-Undang No.23 tahun 2011 Tentang Pengelolaan Zakat disebutkan bahwa zakat wajib didistribusikan kepada mustahik sesuai dengan syariat Islam (Syahriza, Harahap, dan Fuad 2019). Dengan demikian, baik dalam tinjauan syariah (Abdus Sami, 2010); (Efri Syamsul Bahri dan Khumaini 2020), maupun dalam tinjauan regulasi, sasaran dalam penyaluran zakat terdiri dari 8 (delapan) asnaf, yaitu: Fakir, Miskin, Amil, Muallaf, Riqob, Ghorimin, Ibnu sabil dan Fii sabilillah.

Berdasarkan Peraturan BAZNAS No.3 Tahun 2018 Tentang Pendistribusian dan Pendayagunaan, penyaluran zakat dibagi menjadi dua bidang, yaitu: pendistribusian dan pendayagunaan. Pendistribusian diartikan sebagai penyaluran zakat kepada mustahik dalam bentuk konsumtif, sedangkan pendayagunaan adalah pemanfaatan zakat secara optimal tanpa mengurangi nilai dan kegunaannya dalam bentuk usaha produktif, sehingga berdayaguna untuk mencapai kemaslahatan umum.(Efri Syamsul Bahri dan Khumaini 2020)

\section{Efektivitas Penyaluran Zakat}

Di dalam Kamus Besar Bahasa Indonesia (Syahriza, Harahap, dan Fuad 2019), disebutkan bahwa kata efektif berarti dapat membuahkan hasil, mulai berlaku, ada pengaruh/akibat/efeknya. Sedangkan efektivitas menurut Rifaí (2013:132); (Efri Syamsul Bahri dan Khumaini 2020) diartikan sebagai sebuah keberhasilan suatu aktivitas atau kegiatan dalam mencapai tujuan (sasaran) yang telah ditentukan sebelumnya. Penelitian (Susilowati dan Setyorini 2018) menunjukkan efektivitas penyaluran zakat dapat mewujudkan good zakat governance.

Efektivitas penyaluran zakat (Efri Syamsul Bahri dan Khumaini 2020) dapat diukur dengan menggunakan Zakat Core Principles (ZCP). Di dalam ZCP (Hamdani, Nasution, dan Marpaung 2019) terdapat prinsip-prinsip inti zakat yg mencakup 18 aspek terkait pengelolaan zakat yang mengatur 6 (enam) aspek atau dimensi utama pengelolaan zakat. Keenam aspek tersebut terdiri dari: landasan hukum, supervisi zakat, tata kelola zakat, fungsi intermediasi, manajemen resiko dan kesesuaian syariah. 
Tujuan dilakukannya penilaian efektivitas penyaluran zakat dengan menggunakan metode penghitungan ZCP adalah untuk mengetahui tingkat efektifitas penyaluran dana zakat yang dikelola Rumah Zakat sehingga pengelolaannya dapat dipertanggungjawabkan dan dapat mewujudkan good zakat governance. Pengukuran ZCP. ZCP (Rusydiana dan Firmansyah 2017) juga bertujuan untuk memperbaiki kualitas sistem zakat. Model penghitungan Rasio ACR pada ZCP digunakan untuk mengukur kemampuan sebuah lembaga zakat dalam menyalurkan dana zakatnya.

\section{Metode Penelitian}

Penelitian ini menggunakan metode penelitian studi pustaka (Bastiar dan Bahri 2019) dengan cara mengumpulkan dan mempelajari literatur yang telah ada dari berbagai sumber seperti: jurnal, artikel, buku dan proceeding berbagai konferensi. Penelitian studi psutaka (Sawarjuwono 2003) termasuk bentuk penelitian dimana yang menjadi obyek kajian adalah literatur tersebut. Studi literatur (Anjar Wanto, 2019:39); (Efri Syamsul Bahri, Ariwibowo, dan Robbani 2020) dilakukan dengan tujuan untuk melengkapi pengetahuan dasar dan teori dalam penelitian ini. Tujuan studi pustaka (Mulyani 2016) adalah untuk mencari referensi dan teori-teori atau dalil yang mendukung dan berhubungan dengan tema penelitian ini.

Penelitian ini menggunakan rasio Allocation to Collection Ratio (ACR) yang ada dalam Zakat Core Principle (ZCP). Berdasarkan ZCP (Efri Syamsul Bahri dan Khumaini 2020), ACR diperoleh dengan cara membagi total dana penyaluran dengan total dana penghimpunan. Penilaian ACR (BAZNAS 2018) terdiri dari beberapa kategori, dengan rincian sebagai berikut: 1. Highly Effective (jika ACR $\geq 90$ persen) 2. Effective (jika ACR mencapai 70- 89 persen) 3. Fairly Effective (jika ACR mencapai 50- 69 persen) 4. Below Expectation (jika ACR mencapai 20- 49 persen) 5. Ineffective (jika ACR $<20$ persen).

Objek yang digunakan dalam penelitian ini adalah laporan penyaluran Rumah Zakat selama rentang periode 2015 sampai dengan 2019, dimana data diperoleh dari situs Rumah Zakat. Rumah Zakat dipilih menjadi objek penelitian ini, karena merupakan salah satu Lembaga Amil Zakat (LAZ) Tingkat Nasional yang terus tumbuh dan berkembang.

\section{Hasil dan Pembahasan}

\section{Visi, Misi dan Sejarah Rumah Zakat}

Rumah Zakat (RZ) adalah lembaga filantropi yang mengelola zakat, infak, sedekah, serta dana sosial lainnya melalui program-program pemberdayaan masyarakat. Visi RZ adalah Lembaga filantropi internasional berbasis pemberdayaan yang professional. Misi RZ antara lain: (1) Berperan aktif dalam membangun jaringan filantropi internasional; (2) Memfasilitasi kemandirian masyarakat; dan (3) Mengoptimalkan seluruh aspek sumber daya melalui keunggulan insan.

Hasil penelitian yang dilakukan (Andriyanto 2011) menjelaskan bahwa Rumah Zakat didirikan oleh Abu Syauqi pada tanggal 2 Juli 1998 dengan nama Dompet Sosial Ummul Quro (DSUQ). DSUQ mendapat dukungan masyarakat sehingga donasi yang terkumpul selama 1998-1999 sebanyak Rp0,8 miliar. Selanjutnya, Rumah Zakat terus mengalami perkembangan yang siknifikan seiring dengan meningkatkanya kepercayaan para donator, maka jumlah pengumpulan donasi juga terus mengalami peningkatan. Pada tahun 2000 terkumpul donasi Rp.2,1 miliar, tahun 2001 semakin bertambah menjadi 
Rp2,19 miliar. Tahun 2002, identitas lembaga sebagai lembaga amil zakat semakin dikuatkan. Pada tahun 2003, DSUQ berubah nama menjadi Rumah Zakat Indonesia. Melalui SK Menteri Agama RI No. 157 pada tanggal 18 Maret 2003 Rumah Zakat Indonesia DSUQ menjadi Lembaga Amil Zakat Nasional. Penerimaan donasi meningkat tajam khususnya dari bantuan masyarakat untuk program rehabilitasi pasca tsunami Aceh, tercatat Rp. 45,26 miliar donasi terkumpulkan.

Saat ini, Rumah Zakat berkantor pusat di Bandung tepatnya di Jl.Turangga No.33 Bandung. Yayasan Rumah Zakat Indonesia dikukuhkan sebagai Lembaga Amil Zakat (LAZ) Nomor 42 Tahun 2007 pada tanggal 7 Mei 2007. Banyak penghargaan yang telah diraih oleh RZ, antara lain: Anugrah Syariah Republika 2018 sebagai The Most Innovative Phylantrophy Institution, Top Digital Implementation on Social Institution 2019. Top Digital Awards 2019 yang diselenggarakan oleh Madani Solusi Internasional (MSI), TOP Women Professional dari Indonesia TOP Women Awards 2019, The Best CEO 2019 versi majalah SWA, 1st Champion Indonesia Original Brand Award 2018 untuk kategori ZIS, dan banyak lagi yang lainnya.

RZ mempunya Unit Layanan yang begitu memadai sebagaimana disajikan pada Gambar 2. Jumlah Desa Berdaya sebagai master piece program dengan konsep ICD nya mencapai 1.259 Desa. Selain itu, RZ menyediaan 18 Sekolah Juara (bidang pendidikan), 7 Klinik Pratama (bidang kesehatan), 51 Ambulance, 20 Mobul Klinik, 7 Lab Juara, 1 Mobil Jenazah dan 2 Mobil Juara.

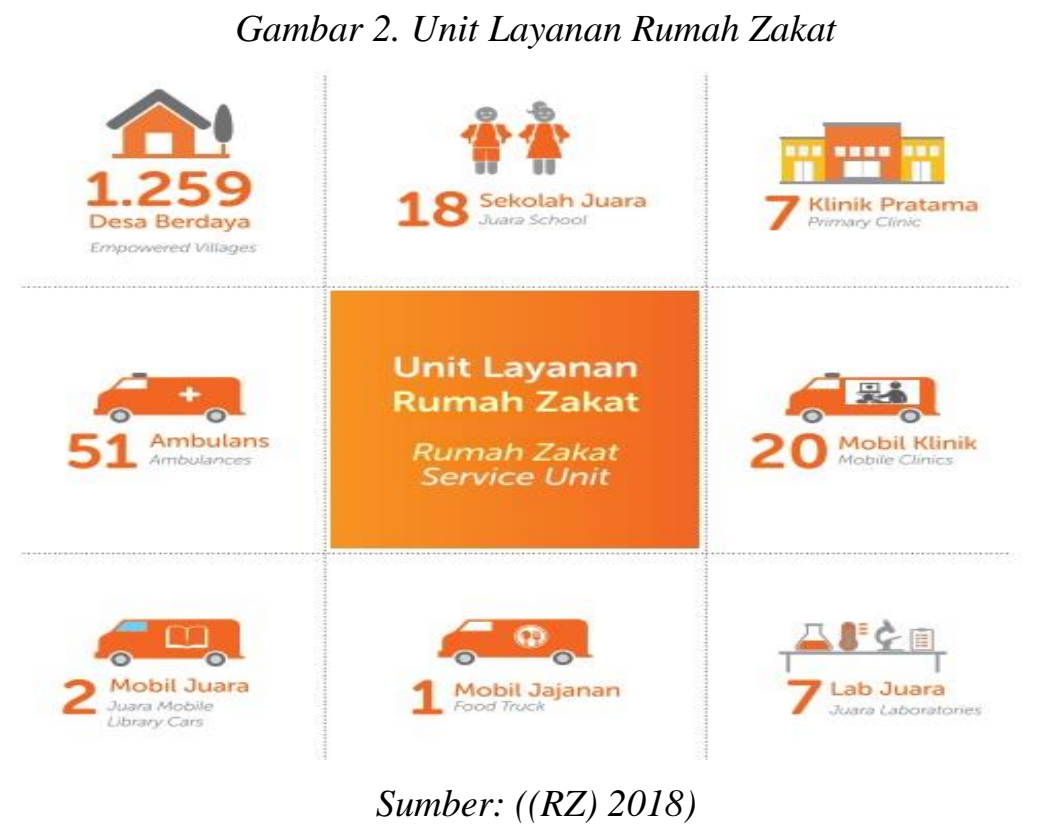

\section{Perkembangan Pengumpulan dan Penyaluran BAZNAS}

Dari aspek pengumpulan, jenis dana yang dikumpukan terdiri dari dana zakat dan infak/sedekah. Pengumpulan donasi pertama kali (Andriyanto 2011) dilakukan tahun 1998 masih dengan nama masih atas nama Dompet Sosial Ummul Quro (DSUQ). DSUQ dimana jumlah yang terkumpul selama 1998-1999 sebanyak Rp0,8 miliar. Pengumpulan zakat dan infak/sedekah yang dilakukan Rumah Zakat terus mengalami peningkatan. Bahkan pada tahun 2019, pengumpulan zakat dan infak/sedekah mencapai Rp244,757,008,372.00. Berdasarkan data pada Tabel 1, jumlah pengumpulan rata-rata 
dalam 5 (lima) tahuan terakhir dari tahun 2015 sampai dengan 2019 sebesar Rp176,298,735,332.80,-.

Tabel 2. Perkembangan Pengumpulan Zakat dan Infak RUMAH ZAKAT Periode Tahun 2015-2019 (Rp)

\begin{tabular}{|c|c|c|c|c|}
\hline No & Tahun & Zakat & Infak & Jumlah \\
\hline 1 & 2015 & $97,666,410,793.00$ & $44,131,559,337.00$ & $141,797,970,130.00$ \\
\hline 2 & 2016 & $109,338,881,331.00$ & $55,612,884,030.00$ & $164,951,765,361.00$ \\
\hline 3 & 2017 & $113,382,621,377.00$ & $49,151,229,474.00$ & $162,533,850,851.00$ \\
\hline 4 & 2018 & $120,580,750,711.00$ & $46,872,331,239.00$ & $167,453,081,950.00$ \\
\hline 5 & 2019 & $199,501,255,609.00$ & $45,255,752,763.00$ & $244,757,008,372.00$ \\
\hline \multicolumn{2}{|c|}{ Nilai Rata-rata } & $128,093,983,964.20$ & $48,204,751,368.60$ & $176,298,735,332.80$ \\
\hline
\end{tabular}

Dari aspek penyaluran sebagaimana disajikan pada table 3, jumlah penyaluran zakat dan infak/sedekah dalam 5 (lima) tahun terakhir antara 2015 sampai dengan 2019 rata-rata sebesar Rp152,627,321,395.80. Penyaluran terbesar pada tahun 2019 telah mencapai Rp229,581,549,037.00. Dana zakat dan infak/sedekah RZ di salurkan untuk 8 (delapan) asnaf antara lain: Fakir, Miskin, Amil, Muallaf, Riqob, Ghorimin, Ibnu sabil dan Fii sabilillah.

Tabel 3. Perkembangan Penyaluran Zakat dan Infak RUMAH ZAKAT

\begin{tabular}{|c|c|c|c|c|}
\hline No & Tahun & Zakat & Infak & Jumlah \\
\hline 1 & 2015 & $91,612,583,464.00$ & $22,943,102,586.00$ & $114,555,686,050.00$ \\
\hline 2 & 2016 & $113,599,505,962.00$ & $28,917,322,703.00$ & $142,516,828,665.00$ \\
\hline 3 & 2017 & $117,151,419,722.00$ & $21,665,887,031.00$ & $138,817,306,753.00$ \\
\hline 4 & 2018 & $120,193,117,257.00$ & $17,472,119,217.00$ & $137,665,236,474.00$ \\
\hline 5 & 2019 & $195,262,816,022.00$ & $34,318,733,015.00$ & $229,581,549,037.00$ \\
\hline \multicolumn{2}{|c|}{ Nilai Rata-rata } & $127,563,888,485.40$ & $25,063,432,910.40$ & $152,627,321,395.80$ \\
\hline
\end{tabular}

Penyaluran zakat dan infak/sedekah RZ mencakup empat rumpun program pemberdayaan yang terdiri dari: Senyum Sehat, Senyum Juara, Senyum Mandiri, dan Senyum Lestari. Keempat rumpun program tersebut dilaksanakan melalui pemberdayaan berbasis wilayah terpadu atau Integrated Community Development (ICD). Pendekatan ICD menjadi konsep RZ dalam melakukan pemberdayaan sehingga selaras dengan Tujuan Pembangunan Millenium atau Millenium Development Goals (MDGs).

RZ menghadirkan Desa Berdaya sebagai proses pemberdayaan wilayah binaan berdasarkan pemetaan potensi lokal. Program pemberdayaan di Desa Berdaya direalisasikan melalui empat rumpun utama yaitu: Senyum Juara (pendidikan), Senyum Sehat (kesehatan), Senyum Mandiri (ekonomi) dan Senyum Lestari (lingkungan). Selain itu RZ juga merupakan lembaga filantropi yang peduli terhadap kemanusiaan. Desa Berdaya menjadi Big Campaign RZ.

Desa Berdaya merupakan cara RZ dalam memberdayakan Indonesia yang terintegrasi di wilayah desa berdasarkan pemetaan potensi lokal di bidang Ekonomi, Lingkungan, Kesehatan, Pendidikan dan Kesiapsiagaan bencana. Berdasarkan infromasi 
yang dimuat di dalam Laporan Tahunan 2018, hingga Desember 2018, Rumah Zakat membina 1259 Desa Berdaya di 213 kota/kabupaten di Indonesia dengan jumlah mustahik yang dilayani sebanyak 4.963.804 jiwa.

\section{Efektivitas Penyaluran Rumah Zakat}

Efektivitas penyaluran menggambarkan pencapaian penyaluran zakat periode tertentu, baik jangka pendek, menengah atau jangka panjang. Untuk mengoptimalkan penyaluran zakat tersebut, maka amil zakat mesti melakukan pengelolaan dengan baik dengan menyusun perencanaan penyaluran, strategi pelaksanaan, pelaksanaan pengendalian serta pelaporan yang baik. Dengan demikian, mustahik merasakan manfaat dan keberkahan zakat. Semakin efektiv penyaluran, maka semakin besar manfaat zakat yang dirasakan oleh mustahik.

Di dalam Zakat Core Principle (BAZNAS, 2016, hal. 26) dijelaskan bahwa untuk menilai kinerja penyaluran zakat dapat dilihat dari rasio pendistribusian terhadap pengumpulan zakat. Semakin tinggi rasio penyaluran terhadap pengumpulan zakat, maka semakin efektif pengelolaan zakat. Tingkat efektifitas yang tinggi juga menggambarkan bahwa zakat dikelola dan disalurkan kepada mustahik dengan baik. Semakin cepat zakat disalurkan kepada mustahik akan semakin baik. Oelh karena itu, cara dan batas waktu penyaluran perlu menjadi perhatian bagi amil zakat.

Pengukuran tingkat efektivitas penyaluran zakat BAZNAS di dalam penelitian ini dilakukan dengan menggunakan metode Zakat Core Principles (ZCP), yaitu: ratio efektivitas penyerapan dana zakatnya atau disebut Allocation to Collection Ratio (ACR). Rasio ACR bertujuan untuk mengukur kemampuan sebuah lembaga zakat dalam menyalurkan dana zakatnya dengan cara membagi total dana penyaluran dengan total dana penghimpunan. Sesuai dengan metode ACR, tingkat efektivitas dibagi kedalam kategori sebagai berikut: 1. Highly Effective (jika ACR $\geq 90$ persen) 2. Effective (jika ACR mencapai 70- 89 persen) 3. Fairly Effective (jika ACR mencapai 50- 69 persen) 4. Below Expectation (jika ACR mencapai 20- 49 persen) 5. Ineffective (jika ACR $<20$ persen).

Berdasarkan ZCP, maka tingkat efektivitas penyaluran selama 5 (lima) tahun dengan periode tahun 2015-2019 sebesar 87\% atau termasuk dalam kategori Effective, dimana Alocation to Collection Ratio (ACR) mencapai $70-89 \%$ persen. Jumlah pengumpulan diperoleh dari rata-rata pengumpulan selama 5 (lima) tahun sebesar Rp 176,298,735,332.80. Sedangkan jumlah penyaluran rata selama periode 2015 sampai dengan 2019 mencapai Rp 152,627,321,395.80.

\section{KESIMPULAN}

Hasil penelitian ini menunjukkan bahwa jumlah pengumpulan rata-rata selama 5 (lima) tahun sebesar Rp176,298,735,332.80. Sedangkan jumlah penyaluran rata selama periode 2015 sampai dengan 2019 mencapai Rp152,627,321,395.80. Hal ini menunjukkan bawah jumlah pengumpulan dan penyaluran zakat dan infak/sedekah selama 5 (lima) tahun terakhir antara tahun 2015 sampai dengan tahun 2019 terus mengalami peningkatan. Penyaluran zakat dan infak/sedekah mencakup 8 asnaf yaitu: Fakir, Miskin, Amil, Muallaf, Riqob, Ghorimin, Ibnu sabil dan Fii sabilillah, yang terbagi dalam empat rumpun program pemberdayaan yaitu: Senyum Sehat, Senyum Juara, Senyum Mandiri, dan Senyum Lestari dengan pendekatan Integrated Community 
Development (ICD) yang selaras dengan Tujuan Pembangunan Millenium atau Millenium Development Goals (MDGs).

Berdasarkan ZCP tingkat efektivitas penyaluran dalam 5 (lima) tahun terakhir yakni antara tahun 2015 sampai dengan 2019 sebesar 87\% atau termasuk dalam kategori Effective, dimana Alocation to Collection Ratio (ACR) mencapai 70-89\% persen. Artinya, zakat dan infak/sedekah disalurkan kepada mustahik secara efektif. Saran dari penelitian ini adalah agar Rumah Zakat dapat meningkatkan efektivitas penyaluran zakat dengan tingkat efektivitas di atas $90 \%$ sehingga masuk dalam kategori Highly Effective jika ACR $\geq 90$ persen).

\section{REFERENSI}

(RZ), Rumah Zakat. 2018. Laporan Tahunan 2018 Rumah Zakat.

Andriyanto, Irsyad. 2011. "Strategi Pengelolaan Zakat dalam Pengentasan Kemiskinan.” Jurnal Walisongo 19(1): 25-46.

Athifah, Ai Nur Bayinah, dan Efri Syamsul Bahri. 2018. "Pengaruh Akuntabilitas Publik dan Transparansi Laporan Keuangan Terhadap Kepercayaan Donatur pada Yayasan PPPA Daarul Qur'an Nusantara.” 2(April): 54-74.

Bahri, Efri S. 2013. Zakat dan Pembangunan Sosial. Cetakan I. ed. Tim FAM Indonesia. Kediri: FAM Publishing.

Bahri, Efri Syamsul. 2015. Meretas Jalan Perubahan. Cetakan pe. Kediri: FAM Publishing.

Bahri, Efri Syamsul, Prasetio Ariwibowo, dan Hamzah Robbani. 2020. "Productive Zakat on Sharia Perspective and Regulation in Indonesia." Jurnal LITERATUS 2(1): 66-76.

Bahri, Efri Syamsul, dan Sabik Khumaini. 2020. "Analisis Efektivitas Penyaluran Zakat pada Badan Amil Zakat Nasional.” Al Maal : Journal of Islamic Economics and Banking 1(2): 164-75.

Bahri, Efri Syamsul, dan Reni Oktaviani. 2019. "Zakat Produktif Sebagai Modal Kerja Usaha Mikro." Perisai : Islamic Banking and Finance Journal 2(2): 101-20.

Bastiar, Yandi, dan Efri Syamsul Bahri. 2019. "Model Pengkuran Kinerja Lembaga Zakat di Indonesia." ZISWAF : Jurnal Zakat dan Wakaf 6(1): 43-64.

Bayinah, Ai Nur. 2019. "Implementasi Zakat Sebagai Pengurang Penghasilan Kena Pajak.” Jurnal Akuntansi Dan Keuangan Islam 3(1): 83-98.

BAZNAS. 2019. Statistik Zakat Nasional 2018. Jakarta: BAZNAS.

BAZNAS, Puskas. 2018. Outlook Zakat Indonesia 2018. https://www.puskasbaznas.com/publications/books/627-outlook-zakat-indonesia2018.

Canggih, Clarashinta, Khusnul Fikriyah, dan Ach. Yasin. 2017. "Potensi dan Realisasi Dana Zakat Indonesia." al-Uqud: Journal of Islamic Economics 1(1): 14-26.

Fadilah, Sri. 2011. "Pengaruh Implementasi Pengendalian Intern dan Total Quality Management Terhadap Penerapan Good Governance (Studi pada Lembaga Amil Zakat Seluruh Indonesia).” In Simposium Nasional Akuntansi SNA XIV Aceh 2011 "Green Concern: Peran Akuntan dalam Mewujudkan Bisnis yang Sustainable, Aceh: Fakultas Ekonomi Universitas Syiah Kuala.

Hamdani, Lukman, M Yasir Nasution, dan Muslim Marpaung. 2019. "Solusi Permasalahan Perzakatan di BAZNAS dengan Metode ANP : Studi tentang 
Implementasi Zakat Core Principles.” Jurnal Muqtasid 10(1): 40-56.

Hazlina Abdul Halim, Jamaliah Said, Sharifah Norzehan Syed Yusuf. 2012. "Individual Characteristics of the Successful Asnaf Entrepreneurs : Opportunities and Solutions for Zakat Organization in Malaysia." Canadian Research \& Development Center of Sciences and Cultures 4(2): 41-49.

Hudayati, Ataina, dan Achmad Tohirin. 2010. "Managemen of Zakah: Centralised vs Decentralised Approach.” In Seventh International Conference - The Tawhidi Epistemology: Zakat and Waqf Economy,.

Indrawati, Rina. 2016. "Evaluasi Penerapan Undang-Undang Pengelolaan Zakat dan Akuntansi Zakat (PSAK 109) pada BAZNAS Provinsi Jatim.” Jurnal Akuntansi AKUNESA 4(2): 1-28.

Johari, Fuadah, Ahmad Fahme Mohd Ali, dan Muhammad Ridhwan Ab. Aziz. 2018. "The Role of Zakat and Success Factor for Muallaf Conditions : An Analysis in Selangor, Malaysia.” Úlum Islamiyyah The Malaysian Journal of Islamic Science 24(August).

Khumaini, Sabik, dan Anto Apriyanto. 2018. "Pemberdayaan Dana Zakat Produktif terhadap Kesejahteraan Umat." Al-Urban 2(1): 32-42.

Marasabessy, Ruslan Husein. 2017. "Analisasi Pola Distribusi Zakat pada Masa Daulah Umayyah dan Abbasiyah.” Jurnal Asy- Syukriyyah 18: 132-50.

Mubarok, Abdulloh, dan Baihaqi Fanani. 2014. "Penghimpunan Dana Zakat Nasional (Potensi, Realisasi dan Peran Penting Organisasi Pengelola Zakat).” Jurnal Permana 5(2): 7-16.

Mulyani, Dwi. 2016. "Model Sistem Informasi Keuangan Bank Sampah Syariah/Micro Finance.” In Prosiding SNRT (Seminar Nasional Riset Terapan) Politeknik Negeri Banjarmasin,.

Nasrulloh. 2019. "Filantropi Islam: Praktek dan Kontribusinya terhadap Ketercapaian Sustainable Development Goals (SDGs)." In Annual Conference for Muslim Scholars, Surabaya, 364-75.

Pratama, Fahrizal Rizky Putra, dan Eko Fajar Cahyono. 2019. "Pengukuran Efisiensi dan Produktivitas Rumah Zakat Indonesia dengan Metode Indeks Malmquist." Jurnal Ekonomi Syaroah Teori dan Terapan 6(4): 774-86.

Riyaldi, Muhammad Haris. 2017. "Kedudukan dan Prinsip Pembagian Zakat dalam Mengatasi Permasalahan Kemiskinan (Analisis Padangan Yusuf Qardhawi).” Jurnal Perspektid Ekonomi Darussalam 3(1): 17-27.

Rusydiana, Aam Slamet, dan Irman Firmansyah. 2017. "Prioritizing Zakat Core Principles Criteria.” Esensi: Jurnal Bisnis dan Manajemen 7(2): 277-302.

Satori Ismail, Ahmad et al. 2018. Fikih Zakat Kontekstual Indonsia. BAZNAS.

Sawarjuwono, Tjiptohadi. 2003. "Intellectual Capital: Perlakuan, Pengukuran Dan Pelaporan (Sebuah Library Research).” Jurnal Akuntansi dan Keuangan 5(1): 35 57.

Susilowati, Dewi, dan Christina Tri Setyorini. 2018. "Efektivitas Tata Kelola Dana Zakat.” Jurnal Akuntansi Multiparadigma JAMAL 9(2): 346-64.

Syahriza, Mulkan, Pangeran Harahap, dan Zainul Fuad. 2019. "Analisis Efektivitas

Distribusi Zakat Produktif dalam Meningkatkan Kesejahteraan Mustahik (Studi

Kantor Cabang Rumah Zakat Sumatera Utara)." AT-TAWASSUTH IV: 137-59. Triyuwono, Iwan. 2001. "Metafora Zakat dan Shari' ah Enterprise Theory Sebagai 
Efri Syamsul Bahri, \& Zainal Arif

Konsep Dasar dalam Membentuk Akuntansi Syari’Ah.” Jurnal Akuntansi dan Auditing Indonesia 5(2): 131-45.

Wulan, Mulyaning, Hera Khairunnisa, dan Efri Syamsul Bahri. 2018. "Internal Audit Role in Digital Zakat Finance (Case Study at a Zakat Institution in Indonesia)." International Conference of Zakat 2018 Proceedings: 179-95.

Wulansari, Sintha Dwi, dan Achma Hendra Setiawan. 2014. "Analisis Peranan Dana Zakat Produktif terhadap Perkembangan Usaha Mikro Mustahik (Penerima Zakat) (Studi Kasus Rumah Zakat Kota Semarang).” Diponegoro Journal of Economics 3(1): 1-15.

Yaacob, Ahmad Che et al. 2013. "Zakat Disbursement via Capital Assistance : A Case Study of Majlis Agama Islam Johor.” Journal of Emerging Economies and Islamic Research 1(2): 1-19.

Yulinartati, Ahmad Roziq, dan Lely Ana Ferawati Ekaningsih. 2013. "Three Circles Model Revitalisasi Lembaga Pengelola Zakat.” Inferensi 7(2): 387. 